\title{
Богословская оценка экономики или Экономика глазами православного богослова
}

\author{
Давид Рахимов, \\ Московский Государственный Университет \\ Moskwa, Rosja \\ sidorov777@gmail.com
}

Иванов Сергей Александрович

Калужская Духовная Семинария

Zaoksij, Rosja

sidorov777@gmail.com

Rachimov D., Ivanov S., Theological evaluation of economics or Economics through the Orthodox theologist point of view, Elpis, 19 2017: 217-222.

Rachimov D., Ivanov S., Teologiczna ocena gospodarki lub Ekonomika oczami prawosławnego teologa, Elpis, 19 2017: 217 -xx.

Аннотация: Осмысление истинной цели экономики. Изобилие и сытость ведут к смерти.

Abstract: Understanding the true purpose of the economy. Abundance and satiety lead to death.

Streszczenie: Zrozumienie prawdziwego celu ekonomiki. Obfitość i sytości prowadzi do śmierci.

Ключевые слова: экономика, экономическая теория, рост экономики, экономический кризис, санкции, возражения на книгу Самуэльсона «Экономикс»

Keywords: Economy, economic theory, economic growth, economic crisis, sanctions, objections to the Economics (Economics Paul Samuelson)

Slowa kluczowe: ekonomia, teoria ekonomiczna, wzrost gospodarczy, kryzys gospodarczy, sankcje, zastrzeżenia odnośnie do książki Samuelsona „Ekonomia”

\section{Вступление}

В конце $\mathrm{XX}$ века в мире возобладало учение об экономике протестантского мировоззрения, призывающее считать целью экономики постоянное накопление денег и удовлетворение пожеланий потребителя. В систему учения встроены разнообразные теории, судящие о причинах изменений, наблюдаемых в процессе хозяйственной деятельности людей. Исследования только этой школы оцениваются Нобелевским комитетом, и принимаются другими без рассуждений. Теории претендуют на математическую точность, однако руководители государств до сих пор не научились, по мнению экономистов, правильно расставлять приоритеты и управлять «системой» для достижения постоянного роста цифровых показателей.

Несмотря на обилие высокотехнологичных товаров, широкий спектр услуг для всех категорий населения, все более пронизывает людей неудовлетворенность настоящим и страх перед будущим. Ожиданиям стройных теорий постоянно мешают «внезапные» процессы, как то значительные колебания цен на энергоресурсы, миграционные волны населения определенного вероисповедания, возмущения, приводящие к разрыву деловых отношений и даже войнам.

\section{Христианское вероучение об экономике}

Обращение к Священному Писанию и Святоотеческому Преданию помогают понять действительное предназначение экономики человека, как домостроительства, и познать законы, которым она определена.

Христианское вероучение рассматривает хозяйственную деятельность человека через действие промысла Божия, Его икономию от создания мира. Бог создал мир и проекцией законов Его явлены нам заповеди. Нарушение заповедей ведет к противопоставлению нарушителя Творцу и мирозданию, влечет нестроения, болезни и смерть. Все происходящее в мире существует по воле Божией, которой содержится и разумно управляется, действие это всесильно, неизменно, никем и ничем непобедимо. Человеческая экономика пребывает в домостроительстве Божьем: ибо все из Него, Им и к Нему (Рим. 11:36). Слово Его 
не возвращается тщетным, но исполняет все, что Ему угодно, совершает все, для чего послано, во славу Его ${ }^{1}$ (Ис. 55:11). Бог наперед знает и помыслы человека, и чувства, и дела ${ }^{2}$ (П. 138:2-4). Суть икономии Бога привести к Себе творение, некогда отпадшее от Него. Промысл Господа направлен на добровольное желание человека истребить в себе страсть гордости, исправить нанесенное самому себе повреждение души.

Потворствуя страсти, человек теряет часть своей свободы и становится рабом страсти, разрушая целостность своего духа. Погружаясь в суету земного, человек становится рабом земли, рабом житейских попечений, уподобляясь скотам несмысленным (Пс. 48:13). Спасение человека заключается в воссоздании всего нарушенного миропорядка, в том числе и подобия Творцу.

«Случайностей в жизни нет и быть не может, Бог-Промыслитель правит миром, и каждое обстоятельство имеет высший духовный смысл и даровано Богом для исполнения этой вечной цели - для познания Бога», - наставляет архимандрит Иоанн (Крестьянкин) (†2006).

\section{Священное Писание и Священное Предание о принципах хозяйственной деятельности}

\section{1. Икономия Бога определяет экономику человека}

Бог-Создатель, сотворив мир, держит в равновесии и управляет всем мирозданием во всех его подробностях для достижения Им предначертанной цели. Так говорит Господь: Я возвещаю от начала, что будет в коние, и от древних времен то, что ещче не сделалось, говорю: Мой совет состоится, и все, что Мне угодно, Я сделаю (Ис. 46:10).

Нарушение законов Творца человеком влечет за собой нестроения и разрушения не только самого человека, но и поставленной от него в зависимость твари: Ибо знаем, что вся тварь совокупно стенает и мучится доныне...(Рим. 8:22). Человек есть часть органического творения. Для пребывания в гармонии с миром человеку необходимо в свободном выборе следовать законам, установленным Творцом:

Для Господа не являются тайной замыслы человека: ни новые открытия, изобретения, суммы депозитов, и последующее их применение. Человек не ведает, как будет, - Бог ведает. У Бога нет забытых людей. Любое событие свершается только по воле Творца, без Него ничего произойти не может, ибо ни у кого ... не пропадет волос с головы, без ведома Бога (Деян. 27:34). Лю-

\footnotetext{
так и слово Мое, которое исходит из уст Моих, - оно не возвращается ко Мне тщетным, но исполняет то, что Мне угодно, и совершает то, для чего Я послал его (Ис. 55:11)

2 все пути мои известны Тебе. Еще нет слова на языке моем, - Ты, Господи, уже знаешь его совершенно (Пс. 138:2-4)
}

бое событие свершается только по промыслу Творца или его попущению, без Него ничего произойти не может. За всем следует видеть руку Божию, очищающую человека от всего греховного, что затаилось в падшей душе.

\section{2. Мир устроен по закону любви}

Ибо Бог есть любовь (1 Ин. 4:7-8). Разнообразные, столь несхожие между собой, части мира соединил Творец любовью. Все, что созидается без любви, временно и разрушается, как дом, построенный на песке.

По закону любви устроен мир и человек. В любви человек отдает, не осуждая и прося ничего взамен: любовь долготерпит, милосердствует, любовь не завидует, любовь не превозносится, не гордится, не бесчинствует, не ищет своего, не раздражается, не мыслит зла, не радуется неправде, а сорадуется истине; все покрывает, всему верит, всего надеется, все переноcum, - учит нас Апостол Павел (1Кор. 13:4-7).

\section{3. О конкуренции. Воля человека ограничена им самим. Во всем остальном действует благая воля Божия}

Свободная воля человеческая имеет в себе столько силы, сколько Бог попускает ей иметь, заранее предвидя ее будущее произволение и действие. В остальном же действует Божия воля. Человек действует под влиянием двух побуждений: корыстолюбия и любви. Решение его способно воздействовать на другого лишь с той силою, что полезна исцелению души другого, и ни на йоту более. Большего Господь не попустит. Человек внимательный убеждается в невозможности исполнения многих своих замыслов, сталкиваясь с противоположной волей людей и непреодолимыми обстоятельствами. Ибо все в мире есть: похоть плоти, похоть очей и гордыня (ср. 1 Ин. 2:16), как для одного, так и для другого. Сердие человека обдумьвает свой путь, но Господь управляет шествием его (Прит. 16:9). Если неопытному суждено пройти часть пути без преград, все, что может ему помешать, улетучится как паутина ветром: ибо Я Господb, Бог твой; держу тебя за правую руку твою, говорю тебе: «Не бойся, Я помогаю тебе» (Ис. 41:13).

Всякий индивид, вступающий в хозяйство, занимает в нем свое, как бы приуготовленное ему место, наиболее для него полезное. В ситуацию, в которой он мог бы наилучшим образом познавать себя: кто он есть, кто он есть перед лицом Бога. Никто другой, кроме нас самих, не может нам вредить, даже дьявол. Но гордая душа - раба страха. Убедив себя в наличии случайностей, человек стал прятаться за страховым полисом от промысла Божьего, как ранее Адам между деревьями рая (ср. Быт. 3:8).

\section{4. Люди не могут обойтись друг без друга. Никто не может заработать для себя, не сделав что-либо для другого}

Соединив мир любовью, Господь зависимыми друг от друга соделал части его. Творец пожелал связать 
свободных людей через потребности, связал работу одного для собственной пользы и для пользы других. Не только бедные нуждаются в богатых, но и богатые в бедных, и даже в еще большей степени. Святитель Иоанн Златоуст (†407) в трактате «О любви» раскрывает замысел: «Поэтому земледелец сеет не столько, сколько хватило бы для него, а работает на благо многих; и купец готовит не столько, сколько достаточно было для него одного, но и для многих других... Ибо раз люди не в состоянии работать на благо ближнего иначе как по принуждению, то Бог не допускает прийти к собственной выгоде иначе как пройдя по пути принесения пользы другим» ${ }^{3}$. Не имея в себе должной любви, удерживаются люди потребностями, чтобы посредством всяких взаимно скрепляющих связей, при действии в свою меру каждого члена, получали приращение для созидания самого себя в любви (Еф. 4:16).

\section{5. Богатство и бедность человека - от Бога. \\ Люди пользуются этими благами временно, как управляющие, верные или не верные}

Суть различия в богатстве земном у людей есть следствие первородного греха. Богатство происходит из неравенства, а, следовательно, из несправедливости. Какой бы проект ни задумал человек, Господь определяет его успешность: ибо легко в очах Господа скоро и внезапно обогатить бедного (1Цар. 2:7). Сегодня богат, а завтра беден. Святитель Иоанн Златоуст разъясняет: «Для того Он и самое обладание богатством сделал ненадежным, чтобы и чрез это самое ослабить безумную страсть к нему» ${ }^{4}$.

Имущественное положение человека само по себе не является свидетельством угодности или неугодности Богу. Ни богатство, ни бедность не составляют сами по себе зла. Губительно не само по себе имущество или золото, но сердечное пристрастие к ним владеющих, ведь оно делает более доступным греховные наслаждения. Устремляясь силами души к накоплению богатства материального, человек вынужден нарушать заповеди и уклоняться от основной Цели. Корысть порождает злобу и многозаботливость: никто не может служить двум господам: ибо или одного будет ненавидеть, а другого любить ... Не можете служить Богу и маммоне (Мф. 6:24).

Устремление сердца к накоплению предполагает долгую старость и страх о невозможности прокормить себя в конце жизни. Трата ограниченного времени жизни для накопления богатства земного делает человека бесполезным для Бога: какая польза человеку, если он приобретет весь мир, а душе своей повредит? (Мф. 16:24). Бедность посылается людям Богом точно так же, как болезнь и другие страдания, - для смирения, чтобы предостеречь их от большего падения. Но не всякая бедность спасительна и угодна Богу: зла бед-

\footnotetext{
3 Свт. Иоанн Златоуст. О любви. Беседа 1 http://azbyka.ru/otechnik /Ioann Zlatoust/o-ljubvi/

4 Свт. Иоанн Златоуст. О статуях. Беседа 2. http://azbyka.ru/otechnik /Ioann Zlatoust/besedy-o-statujah/
}

ность в устах нечестивого (Сир. 13:30). Бедность сама по себе не спасает душу человека.

За праведные дела отцов может наполниться чаша дома, если пребывают их наследники в любви и гармонии между собой, грехами новыми не отторгая благость Бога: ибо Я Господь, Бог твой... творящий милость до тысячи родов любящим Меня и соблюдающим заповеди Мои (Вт. 5:10). Родители, ведя домостроительство в страхе Божием, способствуют пребыванию Божией благодати и на детях своих. Лаконично высказывается преподобный Порфирий Кавсокаливит (†1991): святость родителей спасает их детей

\section{6. Правильным средством приобретения благ материальных является труд}

Во спасение человека Творец промыслительно заповедал Адаму трудиться, в поте лииа добывать необходимое для жизни плоти (Быт. 3:19). Для исполнения человеком заповеди труда даруются каждому свои таланты. Силы и способности - не собственность человека, а даны ему Творцом для выполнения призвания на земле, кому много дано, с того много и спросится (Лк. 12:48). В трудовые отношения между человеком и природой привходит освящающая их благодать Святого Духа. В труде человек приобретает значение: не удивляйся делам грешника, веруй Господу и пребывай в труде твоем (Сир. 11:20). Падший человек вынужден трудиться скорбя, одной лишь нуждой побуждаемый, пытаясь создать искусственный мир, в потоке мнимых ценностей, под гнетом чужих страстей и своих собственных.

\section{7. Мир - единый организм}

Творение пропитано Божьей Мудростью, под видимым, незримым образом пребывает Устроитель всего. Каждый народ расселен на определенную ему Творцом территорию, назначен срок пребывания и период расцвета в истории. Народам отведено каждому свое место, дан собственный характер и предназначение, подобно составу человеческого организма: легкому, почкам, печени. Все включены в общий организм, дополняя друг друга и друг без друга существовать не могут: Бог расположил члены, каждый в составе тела, как Ему было угодно (1Кор. 12:18). Даны каждому народу на его территории все потребное для существования, продолжения рода, лечения плоти, богатства земные как в один век, так и в будущий.

Ни один орган не может быть изолирован от других, не может глаз сказать руке: ты мне не надобна (1Кор. 12:21). Потому как эту недостаток незамедлительно ощутят другие части единого организма. Можно сказать, что все человечество соединено между собой по принципу неслитно, нераздельно, неразлучно

См.: Порфирий Кавсокаливит (†1991). Цветослов советов. http:// azbyka.ru/otechnik/Porfirij_Kavsokalivit/tsvetoslov-sovetov

6 Термины из определения об ипостасном несмешивающемся сочетании божественной и человеческой природы Христа в одной ипостаси (IV Вселенский собор, 451 г.) 
Творец, ведая будущее, дал заранее на потребу ресурсы для настоящего и будущего. Для Германии свое, для Китая свое, для России свое: пей воду из твоего водоема и текущую из твоего колодезя (Прит. 5:15). Неверие в свой народ - это недоверие Творцу. Каждому предназначено свое время и степень благоденствия. Будущее народов строится не столько по человеческому разумению, сколько по неисповедимому Промыслу. Господь ко времени, определенному Им, создаст необходимые условия для расцвета этого народа в борьбе между «градом земным» и «градом Божиим»?

\section{8. Цена на товар определяется Богом - Бог цену строит}

Бог расположил все согласно с мерой, числом и весом (Прем. 11:21) Всему творению утвердил границы и время. Творец мира дает все без цены: пользуйся, славь Господа! И даже поставил человека выше других тварей земных, дав возможность присваивать имена, соучаствовать в оценке сотворенного Им (ср. Быт. 2:20). Цена на товар - малое, что определяет Он в промысле Своем. Спекулянты на рынке прилагают усилия, чтобы повысить цену продажи и снизить ее для покупки, но какова она будет - не ведают: в полу бросается жребий, но все решение его - от Господа (Прит. 16:33). Никто не может сказать наверняка, какова будет цена завтра, через месяц или год. Как бы не пытался человек, но Господь определит границу надменным волнам цены: доселе дойдешь, не перейдешь (Иов. 38:11).

Зараженный страстями разум исказил ценности мира. Не в редкости товара дело, а в прелести, которой человек сам дал власть над собой. Алмаз ценится дороже воды, потому что блестящий камень тешит гордость. Не высоко ценит падший человек и душу свою - то, что, в действительности, и есть самое дорогое, $u$ если он приобретет весь мир, а душе своей повредит? какой выкуп даст человек за душу свою? (Мк. 8:36, 37).

То, что действительно необходимо для быта человека, простые вещи, продукты, имеют невысокую цену. Вредные же для души, тешащие гордость - дороги. Человек, подчиняясь одной страсти, подпадает под вторую и так полного подчинения страстям. Поиск новых вещей и впечатлений является страстью тщеславия, не имеющей границы ${ }^{8}$.

\section{9. Божья воля - это жизнь человека без долгов}

Господь ведает потребности каждого, о каждом непрерывно печется: ибо знает, в чем нуждается человек, прежде чем попросили Его об этом (Мф. 6:8). Падшему человеку трудно довериться Богу. Беря кредит заемщик, не верит во всемогущество промысла Божьего, не доверяет Богу, считая достаток результатом лишь собственных усилий. А если Господь посылает испы-

\footnotetext{
Данилевский Н.Я. Россия и Европа. 1864. С. 51. http://www.rusinst. ru/docs/books/N.Ya.Danilevskii-Rossiya.i.Evropa.pdf

8 Тертуллиан К.С.Ф. Трактат о женских украшениях. http://azbyka. ru/otechnik/Tertullian/o_ukrasheniyah/
}

тание нуждой, то человек не желает этого терпеть, не допускает мысли, что есть воля Божия. Берет кредит, потому деньги хороши, приятны для глаз и вожделенны (Быт. 3:6). Занявший деньги сначала весел, вносит перемены в свою жизнь, ощущая себя как бог. Но дело вдруг идет не так как ожидалось, и видит заемщик, что наг (ср. Быт. 3:7). Жизнь должника становится тягостной, и все его помышления лишь о росте долга. И день уже не светел, и ночь не дает покоя. Падший человек вновь и вновь повторяет поступок первых людей, оправдываясь, как и тогда: змей обольстил меня (ср. Быт. 3:13).

В узы человек попадает по своей воле. Ведая заранее это, Господь заповедал всякому прощать все долги должнику каждый седьмой год9. Бог хочет, чтобы человек был свободен, чтобы сердце человека принадлежало Господу полностью. По прощении долга бедный так и останется бедным ${ }^{10}$, но у него будет временное облегчение от бремени, чтобы получив послабление, смог он восславить Господа. Тем более тяжко бремя долговое, если должник - вся страна: лучше немногое при страхе Господнем, нежели большое сокровище и при нем тревога (Прит. 15:16). Не надо бояться бедности. Никто не винит за нее, потому как зло непроизвольно, но если обяжешься платить рост, то всякий станет упрекать за безрасчетность. Никто не лечит раны раною, не врачует зла злом, и бедности не поправишь платою роста: отдавайте всякому должное... не оставайтесь должными никому ничем, кроме взаимной любви (Рим. 13:7,8).

Дающий же в рост сеет без земли, не сеяв - жнет. Ибо неизвестно, кому достанется скопленное ростом богатство, собрав ростовщику одно зло неправды на суде Божьем, - наставляет свт. Иоанн Златоуст ${ }^{11}$.

\section{0. Форма зависит от состояния духа}

Состояние здоровья общества и человека определяется духом, пребывающим в них. Дух Божий объединяет, сочетает, является источником жизни; дух же сатанинский разделяет, приводит к разрушению и самоуничтожению.

От состояния Церкви зависит состояние всего государства. И если Церковь обмирщается, теряет устремленность к Богу, старается угодить страстям мира сего, то множатся в обществе нестроения и бунты. Церковь как соль - сохраняет, скрепляет, очищает, придает вкус (смысл) жизни: Дух животворит, плоть не пользует нимало (Ин. 6:53-63).

\footnotetext{
9 1. В седьмой год делай прощение. 2. Прощение же состоит в том, чтобы всякий заимодавец, который дал взаймы ближнему своему, простил долг и не взыскивал с ближнего своего или с брата своего, ибо провозглашено прощение ради Господа (Бога твоего) (Втор. 15:1, 2).

10 Ибо нищие всегда будут среди земли (твоей) (Втор. 15:11).

11 Свт. Василий Великий. Беседы на псалмы. Беседы на окончание 14-го псалма и ростовщиков (см.: http://azbyka.ru/audio/vasilij_ velikij_besedy_na_psalmy.html)
} 


\section{Этический кодекс экономического поведения}

Господь наш Иисус Христос указал один путь спасения, для всех христиан. Нет особого пути стяжания Духа Святого: одного для монахов, другого - для мирян; нет двух христианств. Поэтому и мирянину в суете повседневных забот необходимо придерживаться Богоугождения и духовного делания - Иисус Христос вчера и сегодня и во веки Тот же (Евр.13:8). Поскольку всякое падение человеческое, начиная с прародителей, обусловлено проникновением в душу и сочетанием с ней духа гордыни, то воссоздание личности, ее спасение происходит только через стяжание прямо противоположного качества души. Воссоздание личности, ее спасение происходит только через развития в себе:

\section{1. Смирения и терпения}

Надлежит в труде сделаться добрым по своей воле, сердия сокрушенного и смиренного Бог не уничижит (Пс. 50:19). Любовь к ближнему неотделима от смирения. Кто переносит благодушно встречающиеся неприятности, принимая их как от руки Господней, тот причастником бывает мученичества, терпением вашим спасайте души ваши (Лк. 21:19). Апостол Павел учит: В скорби будьте терпеливы, в молитве постоянны (Рим.12:12). Терпение есть состояние духа и корень всех благ, по слову святых отцов ${ }^{12}$. Чтобы усвоить себе дух всепрощения с сердцем милосердным благословляйте гонителей ваших; благословляйте, а не проклинайте... (Рим. 12:14). И если мы уповаем на Бога, то имеем терпение.

\section{2. Пребывать в труде с молитвой}

Труд заповедан человеку как спасительное средство. От праздности множатся пороки. Потому и апостол Павел учил: если кто не хочет трудиться, тот и не ешь (2 Фес. 3:10). Трудиться следует по потребности, потому что излишнее богатство похоже на нищету ${ }^{13}$.

Трудясь, помнить следует, что ничего благого для Господа мы сотворить не в силах, ведь все труды человека - для рта его (Еккл. 6:7). Потому и в молитве говорится: яко николеже сотворих благое пред Тобою ${ }^{14}$, чтобы это не послужило соблазном для греха гордости.

От веры человека зависит, как он проходит свой путь, а не от времени, места и должности. Господь заботится о нас, умножая Свою благодать и преизобильно изливая ее на каждую заблудшую душу. Однако детям не полезно оставлять значительное наследство, так как оно несет в себе вред для них. Святитель Николай

\footnotetext{
12 свт. Иоанн Златоуст, 45, 866-867

13 Свт. Игнатий (Брянчанинов) Т.4 Аскетическая проповедь. Поуч.. в 26 неделю.

14 Молитва 1-я, святого Макария Великого
}

Сербский (†1956) учит оставлять детям в наследство навык к труду ${ }^{15}$.

\section{3. Всецелая преданность воле и Промыслу Божиим}

В труде надеяться надо не на себя, а на помощь Божию. Исаак Сирин в слове 49-м пишет: «Как скоро человек отринет от себя всякую видимую помощь и человеческую надежду, и с верою и чистым сердцем пойдет вослед Богу: тотчас последует за ним благодать, и открывает ему силу свою в различных воспоможениях». В любом деле нам следует предавать себя в руки Божии и чтить Бога как Бога - что Он Всеблагой, Всесовершенный и Любящий. Если мы с любовью и доверием относимся к Нему, то мы усваиваем себе Его любовь.

\section{4. Быть милосердным ко всем, без лицеприятности}

Господь учит приобретать себе друзей богатством неправедным, то есть богатством материальным, имуществом, деньгами, чтобы приобрести себе молитвенников перед Богом. Использовать даруемое неправедное для обретения богатства праведного, духовного. Чтобы когда обнищаете, приняли вас в вечные обители (Лк. 16:9). Следует в каждом видеть спасающегося грешника: Просящему давай. Благотворящий бедному дает взаймы Господу, и Он воздаст ему за благодеяние (Прит. 19:17). Нищим бедность и болезни даны для их смирения. Ибо нищие всегда будут среди земли твоей; потому я и повелеваю тебе: отверзай руку твою (Втор. 15:11).

Молитву же следует вплести в свою жизнедеятельность: непрестанно молитесь, за все благодарите (1Фес.5:17). Благодать охраняет молящегося. Всякое дело, которое не совершается благодатью Божией, искоренится (ср. Мф.15:13). А соединяющийся с Господом есть один дух с Господом (1Кор.6:17). Деловые отношения должны быть предельно упрощены: $\partial а$ будет слово ваме: да, да; нет, нет; а что сверх этого, то от лукавого (Мф.5:37).

\section{Заключение}

В попущенном технократическом пути развития Господь дает познать малую часть Творения, чтобы оценил человек бесконечную, непостижимую благость Божию и, почтив земные блага благочестивым разумением и созерцанием их, всеми силами устремился к приобретению благ небесных ${ }^{16}$.

\footnotetext{
15 Свт. Николай Сербский. Десять Божиих заповедей. Четвертая заповедь (см.: http://azbyka.ru/otechnik/Nikolaj_Serbskij/desjatbozhiikh-zapovedej).

16 Епископ Игнатий (Брянчанинов). Аскетические опыты. Т. 1.

Ч. 1.31 (см.: http://azbyka.ru/otechnik/Ignatij_Brjanchaninov/tom1_ asketicheskie_opyty/)
} 
Как Господь старается спасти человека, так дьявол - погубить. Удовольствия и соблазны попущены человеку для выявления в нем склонности ко греху: горе миру от соблазнов, ибо надобно прийти соблазнам, но горе тому человеку, через которого соблазн приходит (Мф. 18:7). Горе наживающихся на простоте заемщиков, горе соблазняющих удовольствиями, горе обещающих счастье земное. Увлекаясь мирской хозяйственной деятельностью, человек постоянно сталкивается с действием благой воли Господа, помогающей спастись или препятствующей ослепленному суетой человеку пасть ниже. Богу сердце нужно (ср. Пр.23:26).
Святитель Филарет Московский († 1867) указывал на беспочвенность страха богатых за обнищание мира, если бы всех охватил дух нестяжания. Богатство мира столь велико, что раздавая излишек бедным, богатые все равно оставались бы богатыми по причине недостаточности числа нищих. Мир нестяжательный был бы богаче мира любостяжательнаго ${ }^{17}$. Однако миру, устремленному к роскоши, это не грозит.

17 Свт. Филарет Московский (Дроздов)) Беседа к Братству Николаевского Угрешского Общежительного монастыря. https:/azbyka.ru/ otechnik/Filaret_Moskovskij/slova/288

\section{Литература}

Епископ Игнатий (Брянчанинов). Аскетические опыты. Т. 1. Ч. 1.31 (см.: http://azbyka.ru/otechnik/Ignatij_Brjanchaninov/tom1_asketicheskie_opyty/)

Епископ Свт. Игнатий (Брянчанинов) Т.4 Аскетическая проповедь. Поуч.. в 26 неделю.

Свт. Филарет Московский (Дроздов)) Беседа к Братству Николаевского Угрешского Общежительного монастыря. https://azbyka.ru/otechnik/Filaret_Moskovskij/slova/288

Свт.НиколайСербский.ДесятьБожиихзаповедей.Четвертаязаповедь(см.:http://azbyka.ru/otechnik/Nikolaj_Serbskij/ desjat- bozhiikh-zapovedej).
Тертуллиан К.С.Ф. Трактат о женских украшениях. ttp:// azbyka.ru/otechnik/Tertullian/o ukrasheniyah/

Свт.Василий Великий. Беседы на псалмы. Б еседы на окончание14-го псалма (см.:http://azbyka.ru/audio/vasilij_velikij _besedy_na_psalmy.html)

Данилевский Н.Я. Россия и Европа. 1864. http://www.rusinst. ru/docs/books/N.Ya.Danilevskii-Rossiya.i.Evropa.pdf

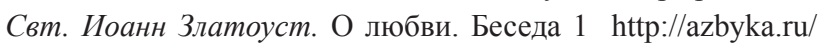
otechnik/Ioann_Zlatoust/o-ljubvi/

Свт. Иоанн Златоуст. О статуях. Беседа 2. http://azbyka.ru/ otechnik/Ioann_Zlatoust/besedy-o-statujah/

Rozmiar artykułu: 0,7 arkusza wydawniczego 
ISSN 1508-7719

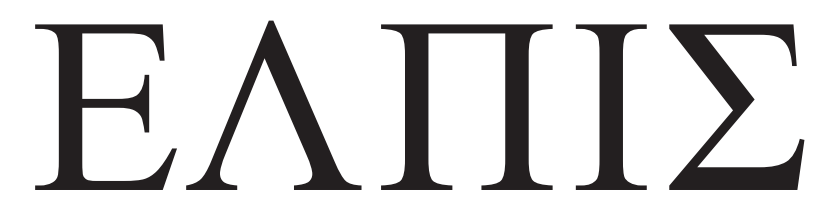

CZASOPISMO TEOLOGICZNE KATEDRY TEOLOGII PRAWOSŁAWNEJ UNIWERSYTETU W BIAŁYMSTOKU

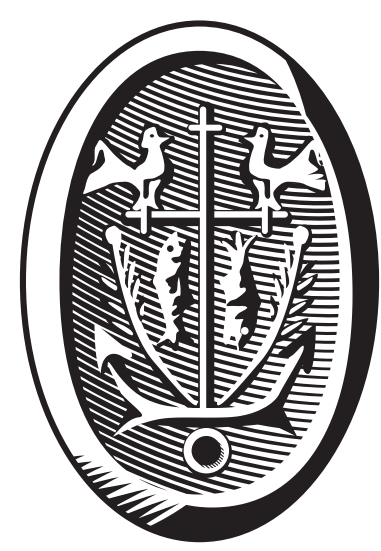

ADRES REDAKCJI

15-097 Białystok, ul. M. Skłodowskiej-Curie 14 tel. 85 745-77-80, e-mail: redakcja@elpis.edu.pl www.elpis.uwb.edu.pl 